\title{
RAPD and SCAR markers linked to resistance to frogeye leaf spot in soybean
}

\author{
Sebastião Martins Filho ${ }^{1}$, Carlos Sigueyuki Sediyama ${ }^{2,3}$, Maurilio Alves Moreira ${ }^{2,4}$ \\ and Everaldo Gonçalves de Barros ${ }^{2,5}$ \\ ${ }^{1}$ Departamento de Engenharia Rural, UFES, Alegre, ES, Brazil. \\ ${ }^{2}$ Instituto de Biotecnologia Aplicada à Agropecuária (BIOAGRO). \\ ${ }^{3}$ Departamento de Fitotecnia, Universidade Federal de Viçosa, Viçosa, MG, Brazil. \\ ${ }^{4}$ Departamento de Bioquímica e Biologia Molecular, Universidade Federal de Viçosa, Viçosa, MG, Brazil. \\ ${ }^{5}$ Departamento de Biologia Geral, Universidade Federal de Viçosa, Viçosa, MG, Brazil.
}

\begin{abstract}
The soybean (Glycine max (L.) Merrill) frogeye leaf spot is caused by the fungus Cercospora sojina Hara and is a widespread disease in Brazil and other countries, causing severe losses in grain yield and also affecting seed quality. The availability of DNA markers linked to genes for resistance to this disease would accelerate breeding programs, particularly when other traits are also being evaluated. Bulked segregant analysis was applied to $3 F_{2}$ populations derived from crosses between the resistant cultivars Parana, Cristalina and Uberaba, and the susceptible cultivar Bossier. In the cross 'Parana' $x$ 'Bossier', 2 RAPD markers were identified, CSOPA $1_{800 \mathrm{C}}$ and CSOPA2 ${ }_{1,250 \mathrm{C}}$, located at $4.4 \pm 1.8$ centiMorgans $(\mathrm{cM})$ and $3.4 \pm 1.7 \mathrm{cM}$ respectively from the resistance locus. DNA fragments of similar molecular weight were observed in the population derived from the cross 'Cristalina' $x$ 'Bossier' at $2.3 \pm 1.2$ and $4.7 \pm 1.5 \mathrm{cM}$ from the resistance locus, respectively. In the offspring of the cross 'Uberaba' $\mathrm{x}$ 'Bossier', a DNA fragment corresponding to marker CSOPA $1_{800 c}$ was detected at $5.6 \pm 2.1 \mathrm{cM}$ from the resistance locus. Although marker CSOPA2 $2_{1,250 \mathrm{C}}$ was not observed in this population, an additional marker was detected (CSOUB1 $\left.1_{1,100 \mathrm{C}}\right)$ at $6.7 \pm 2.2 \mathrm{cM}$ from the resistance locus. The $1,250 \mathrm{bp}$ fragment of $\mathrm{CSOPA} 2_{1,250 \mathrm{c}}$ was cloned and converted into a SCAR marker, which amplified a single fragment whose size corresponded to the cloned segment of the crosses involving cultivars Cristalina and Parana. Markers CSOPA $1_{8000}$, CSOPA2 $_{1,250 c}$ and CSOUB1 $1_{1,100 c}$ were mapped to soybean linkage group $\mathrm{J}$ with the aid of known SSRs linked to the Rcs3 locus, indicating that the RAPD and SCAR markers identified in our research also tag this resistance gene.
\end{abstract}

Key words: molecular markers, RAPD, SCAR, soybean, Cercospora sojina, frogeye leaf spot.

Received: July 19, 2000; accepted: June 6, 2002.

\section{Introduction}

Frogeye leaf spot, caused by the fungus Cercospora sojina Hara, is a worldwide important soybean disease, causing both yield losses and seed deterioration. The use of resistant cultivars is the most efficient and costeffective means of controlling this disease, but the existence of several C. sojina races (Yorinori, 1989b) demands the permanent search for new sources of resistance and their incorporation into resistance breeding programs. Another factor to be considered is that the evaluation of soybean crops with regard to this disease is a timeconsuming process, which requires expertise for the precise distinction between susceptible and resistant plants.

Send correspondence to E.G.de Barros. E-mail: ebarros@mail. ufv.br.
These problems can be better managed in breeding programs by identifying and using DNA markers linked to resistance genes. DNA markers are abundant and essentially independent from environmental conditions (Keim et al., 1989), and several research groups have been using this tool in breeding programs (Shoemaker et al., 1992; Young and Kelly, 1996; Young et al., 1998). In this paper, we report on the identification of DNA markers linked to soybean loci responsible for resistance to $C$. sojina in soybean cultivars Cristalina, Parana and Uberaba, and also on the confirmation of the resistance locus identity.

\section{Material and Methods}

\section{Genetic material and crosses}

Seeds of the soybean cultivars Bossier, Cristalina, Paraná and Uberaba were provided by the Soybean 
Breeding Laboratory (SBL) of the Department of Plant Sciences of the Federal University of Viçosa, Minas Gerais, Brazil. The Bossier cultivar is susceptible to the race $4 C$. sojina fungus, while 'Cristalina', 'Parana' and 'Uberaba' are resistant to it. A number of allelism tests involving these resistant cultivars and/or their resistant progenitors indicate that they harbor the same resistance locus, Rcs3, which is also present in cultivar Davis (Arias et al., 1996).

\section{Origin and cultivation of $C$. sojina isolate}

The monosporic isolate (provided by the SBL) used in all inoculations was collected in the Alto Paranaíba region of the Brazilian State of Minas Gerais, and identified as race 4 (Machado et al., 1997), its isolation and cultivation being carried out as described by Veiga (1973) and Cordeiro (1986).

\section{Evaluation of symptoms}

The crosses performed were 'Cristalina' $\mathrm{x}$ 'Bossier' (CB), 'Parana' x 'Bossier' (PB), and 'Uberaba' x 'Bossier' (UB), with 'Bossier' as the male parent in all crosses. $F_{1}$ plants were selfed, and the $\mathrm{F}_{2}$ seeds were planted in a greenhouse. In addition to the parents, $219 \mathrm{CB}, 126 \mathrm{~PB}$, and 124 $\mathrm{UB} \mathrm{F}_{2}$ plants were tested for resistance/susceptibility to $C$. sojina. The primary leaf from each plant was collected and kept at $-80^{\circ} \mathrm{C}$. When the first trifoliolate leaf was fully expanded, the plants were inoculated with the pathogen by spraying approximately $4 \times 10^{5}$ conidia on each plant, on the abaxial and adaxial sides of the leaves (Casela et al., 1979). The plants were then transferred and kept for 3 days in a mist chamber maintained at 20 to $22{ }^{\circ} \mathrm{C}$ and $95 \%$ relative humidity.

Symptoms were assessed 20 days after inoculation, based on the scale proposed by Yorinori (1989a). To suit our purpose better, the scale was modified as follows: grade $1=$ leaf without lesions; $2=1$ to $10 \%$ of leaf area infected (LAI); $3=11$ to $25 \% \mathrm{LAI} ; 4=26$ to $50 \% \mathrm{LAI}$; and $5=$ more than $50 \%$ LAI. Plants with scores from 1 to 3 were considered resistant, and those which scored 4 and 5 were considered susceptible.

\section{DNA bulks and amplification}

In order to identify homozygous $\mathrm{F}_{2}$ plants for the construction of DNA bulks, $20 \mathrm{~F}_{3}$ seeds were taken from each of $30 \mathrm{~F}_{2}$ resistant plants (with score 1) and planted in a greenhouse; the resulting $\mathrm{F}_{3}$ plants were inoculated with the pathogen and evaluated for symptoms, as described above.

For each cross, two DNA bulks (Michelmore et al., 1991) were constructed, one containing DNA from 6 homozygous susceptible $\mathrm{F}_{2}$ plants, and the other containing DNA from 6 resistant plants. The DNA was extracted by the method described by Doyle and Doyle (1990), and RAPD DNA amplification was carried out by the method of Williams et al. (1990), using primers from Operon Tech- nologies (Alameda, CA, USA) and a model 9600 thermocycler (Perkin-Elmer, Norwalk, CT, USA). 1,200 primers were tested for DNA amplification. Amplification conditions were as follows: 40 cycles, each consisting of a $15 \mathrm{~s}$ denaturation step at $94{ }^{\circ} \mathrm{C}$, a $30 \mathrm{~s}$ annealing step at $35^{\circ} \mathrm{C}$, and a 1 min extension step at $72^{\circ} \mathrm{C}$. After the $40^{\text {th }}$ cycle, a final extension step of $7 \mathrm{~min}$ at $72{ }^{\circ} \mathrm{C}$ was performed. The amplification products were separated on $1.2 \%$ agarose gel containing $0.2 \mu \mathrm{g} / \mathrm{mL}$ ethidium bromide, immersed in $\mathrm{pH} 8.0$ TBE $(90 \mathrm{mM}$ Tris-borate buffer, $1 \mathrm{mM}$ EDTA), and the DNA bands were observed under UV light and photographed; only the most intense and reproducible bands were used for analysis. Primers generating DNA bands which were polymorphic between the bulks were individually tested against the components of each bulk and then tested against the $F_{2}$ population, to determine the genetic distances between the markers and the resistance loci.

\section{Development of SCAR markers}

One of the RAPD bands linked to the resistance locus identified in population CB was excised from the gel, purified with the aid of the Glass Max ${ }^{\mathrm{tm}}$ DNA Isolation Matrix System (BRL) and cloned in the vector pGEM-T Easy (Promega). White colonies were grown in $2 \mathrm{~mL} \mathrm{LB}$ medium containing $100 \mu \mathrm{g} / \mathrm{mL}$ ampicillin, and the plasmid was purified with the QIA Prep Spin Miniprep kit (Qiagen). The clone was partially sequenced by automated sequencing using M13 universal primers. The sequence information was used to design two primers, each one containing 18 nucleotides including the sequence of the original RAPD primer.

The PCR reaction to amplify the SCAR marker consisted of 35 cycles, each one consisting of a $30 \mathrm{~s}$ step at $94{ }^{\circ} \mathrm{C}$, a 1 min step at $62^{\circ} \mathrm{C}$, and a 1 min 30 s step at $72{ }^{\circ} \mathrm{C}$. The amplified bands were analyzed as described for the RAPD amplification products.

\section{Linkage analysis}

Student's chi-square $\left(\chi^{2}\right)$ test was used to analyze the phenotypic segregation of the three populations and to determine possible linkages between the RAPD markers and the resistance loci.

For linkage analysis, $219 \mathrm{CB}, 126 \mathrm{~PB}$, and $124 \mathrm{UB} \mathrm{F}_{2}$ plants were used, and the progenitors of these crosses were also tested with primer-pairs for SSR Satt-547 and Satt-431, which were shown to be linked to the Rcs3 locus in soybean linkage group J (Mian et al., 1999). Where polymorphic bands were detected, the contrasting bulks and the $\mathrm{F}_{2}$ plants were also analyzed. The distances between the molecular marker loci and the resistance locus were estimated using version 3.0 of the MAPMAKER/EXP program (Lander et al., 1987; Lincoln et al., 1992), with a minimum lod score of 3.0 and a recombination setting of $50 \%$. 


\section{Results and Discussion}

\section{Identification of RAPD markers}

Figure 1a and $1 \mathrm{~b}$ show the two polymorphic DNA bands which distinguished the contrasting bulks from the PB cross. These bands were present in all resistant individuals of the bulks and absent in all susceptible individuals. These markers were designated CSOPA $1_{800 \mathrm{C}}$ and CSOPA $2_{1,250 \mathrm{C}}$, because they are linked to a locus which
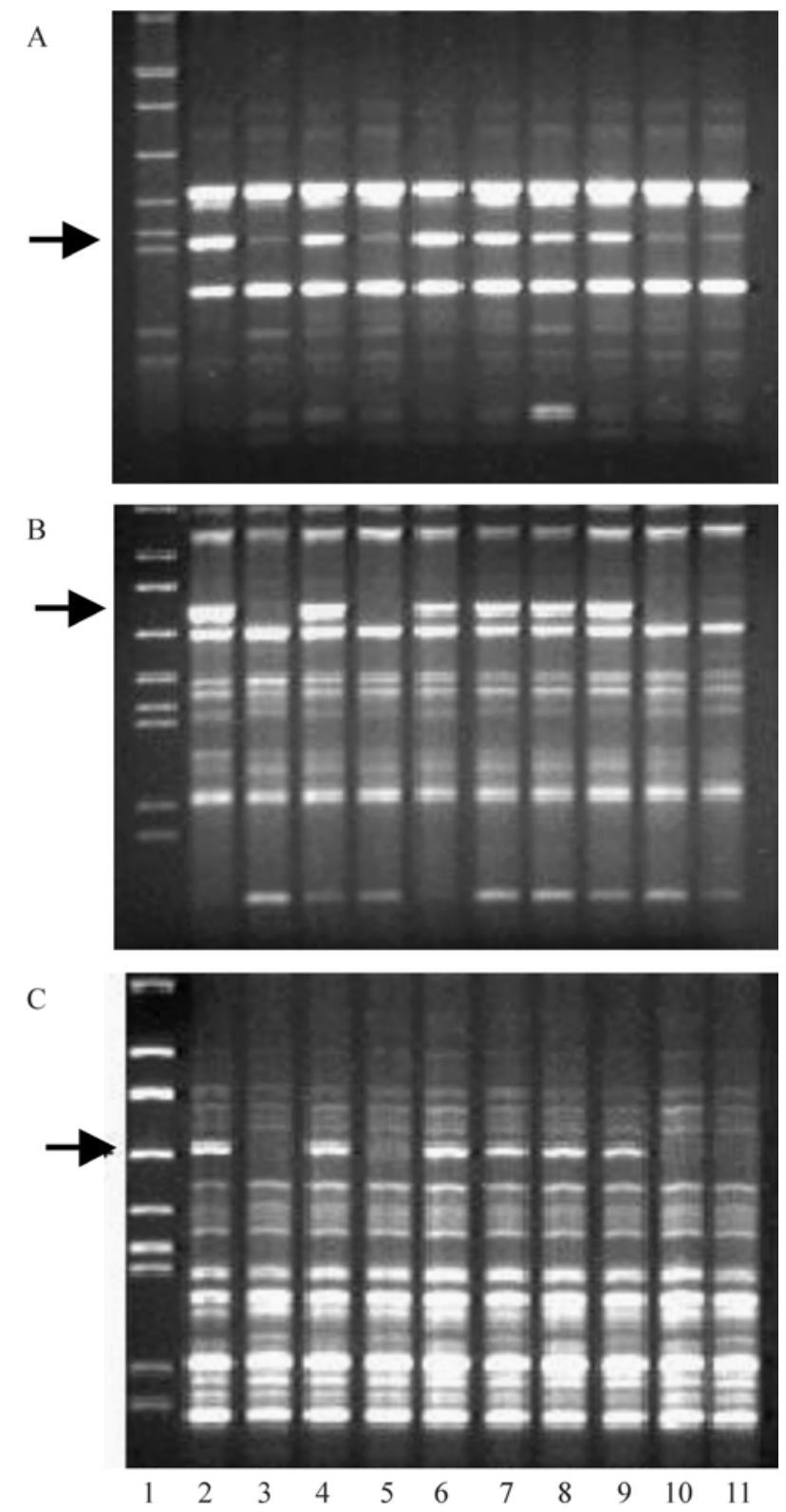

Figure 1 - Gels of DNA amplification products from soybean plants with different susceptibility to frogeye leaf spot: a) marker CSOPA $1_{800 \mathrm{C}}$ in the $\mathrm{PB}$ cross, b) marker $\operatorname{CSOPA} 2_{1,250 \mathrm{C}}$ in the $\mathrm{PB}$ cross, c) marker CSOUB $1_{1,100 \mathrm{C}}$ in the UB cross. Lanes are as follows: 1, lambda phage DNA digested with EcoRI, BamHI and HindIII (size markers); 2, resistant cultivar; 3, susceptible cultivar; 4, resistant bulk; 5, susceptible bulk; 6-9, resistant $\mathrm{F}_{2}$ plants; and 10-11, susceptible plants. Arrows indicate the polymorphic DNA band. controls resistance to $C$. sojina (CSO) originally detected in cultivar Parana (PA), contain approximately 800 and $1,250 \mathrm{bp}$, respectively, and are in the coupling-phase (C) with regard to the resistance gene. These two markers also co-segregated with resistance in the CB cross. Marker CSOPA $1_{800 \mathrm{C}}$ also co-segregated with resistance in the UB cross, but locus CSOPA2 $2_{1,250 \mathrm{C}}$ was monomorphic in that cross. A third marker, CSOUB1 $1_{1,100 \mathrm{C}}$, was detected only in the UB cross (Figure 1c).

The segregation ratio 3:1 (resistant:susceptible or band presence:absence) in the $\mathrm{F}_{2}$ populations was consistent with the single-factor dominant inheritance of the resistance locus and of the RAPD markers in the $\mathrm{CB}$ and PB crosses (Table I). In the UB cross, resistance to C. sojina segregated at a 13:3 ratio (Table I), indicating that at least two independent loci control resistance in the Uberaba cultivar, one being dominant and the other recessive. Cordeiro (1986) also detected two resistance loci to C. sojina race 4 in a cross between 'Santa Rosa' and 'Bossier', 'Santa Rosa' being the progenitor of 'Uberaba'.

In view of the high $\chi^{2}$ values, the hypothesis of independent linkage (9:3:3:1) could be discarded, indicating that the RAPD markers were linked to the resistance locus (Table II). The estimates of the genetic distance between the RAPD locus CSOPA $1_{800 \mathrm{C}}$ and the resistance locus varied between $2.3 \mathrm{cM}$ for the $\mathrm{CB}$ cross and $5.6 \mathrm{cM}$ for the $\mathrm{UB}$ cross. The estimated genetic distances between RAPD locus CSOPA $2_{1,250 \mathrm{C}}$ and the resistance locus varied between $3.4 \mathrm{cM}$ for the $\mathrm{PB}$ cross and $4.7 \mathrm{cM}$ for the $\mathrm{CB}$ cross. CSOUB $_{1,100 \mathrm{C}}$ was $6.7 \mathrm{cM}$ from the resistance locus.

It is conceivable that the locus tagged by CSOPA $1_{800 \mathrm{C}}$ in all three crosses corresponds to locus Rcs3, a resistance locus previously identified in the cultivars Parana, Cristalina, Santa Rosa and Davis (Arias et al., 1996). To confirm this hypothesis, two SSR markers, Satt 431 and Satt 547 , previously shown to be linked to locus Rcs3 (Mian et al., 1999), were tested in the three populations used in this study (Table I). The results show that, in the CB population, Satt 431 and Satt 547 co-segregated with resistance and with the CSOPA $1_{800 \mathrm{C}}$ and CSOPA $2_{1,250 \mathrm{C}}$ markers. However, in the PB population, both SSR markers were monomorphic, Satt 547 alone being polymorphic in the UB population and co-segregating with resistance and with the CSOPA $1_{800 \mathrm{C}}$ and CSOUB $1_{1,100 \mathrm{C}}$ markers. These SSR and RAPD marker data strongly suggest that the resistance locus we mapped in the three populations corresponds to the resistance locus Rcs3.

It is noteworthy that this conclusion could only be reached by the combined analysis of the two types of markers. In addition, our results confirm the usefulness of the integrated SSR map for soybean (Cregan et al., 1999) as a main guide for breeders and emphasize that the optimal use of molecular markers in plant breeding will depend on a specific analysis of each individual cross. 
Table I - Segregation analysis of molecular markers and the C. sojina resistance locus in $\mathrm{F}_{2}$ populations derived from the crosses 'Cristalina' $\mathrm{x}$ 'Bossier' (CB), 'Parana' $\mathrm{x}$ 'Bossier' (PB) and 'Uberaba' x 'Bossier' (UB) ${ }^{1 /}$

\begin{tabular}{|c|c|c|c|c|c|}
\hline Population & Locus tested & Observed frequency & Expected frequency & $\chi^{2}$ & $\mathrm{p}$ \\
\hline $\mathrm{CB}$ & $\operatorname{Rcs} 3^{2 /}$ & $162: 57$ & $164.25: 54.75$ & 0.0745 & 0.79 \\
\hline $\mathrm{CB}$ & CSOPA $1_{800 \mathrm{C}}$ & $159: 60$ & $164.25: 54.75$ & 0.5495 & 0.46 \\
\hline CB & CSOPA $2_{1,250 \mathrm{C}}$ & $155: 64$ & $164.25: 54.75$ & 1.8645 & 0.17 \\
\hline $\mathrm{CB}$ & Satt-547 & $155: 64$ & $164.25: 54.75$ & 1.8645 & 0.17 \\
\hline $\mathrm{CB}$ & Satt-431 & $159: 60$ & $164.25: 54.75$ & 0.5495 & 0.46 \\
\hline PB & $R \operatorname{cs} 3$ & $98: 28$ & $94.50: 31.50$ & 0.3809 & 0.54 \\
\hline PB & CSOPA $_{800 \mathrm{C}}$ & $95: 31$ & $94.50: 31.50$ & 0.0000 & 0.99 \\
\hline PB & CSOPA $2_{1,250 \mathrm{C}}$ & $94: 32$ & $94.50: 31.50$ & 0.0000 & 0.99 \\
\hline PB & Satt-547 & $-3 /$ & - & - & - \\
\hline PB & Satt-431 & - & - & - & - \\
\hline UB & Res3 & $103: 21$ & $100.75: 23.25$ & 0.1621 & 0.69 \\
\hline UB & CSOPA $1_{800 \mathrm{C}}$ & $97: 27$ & $93.00: 31.00$ & 0.5269 & 0.47 \\
\hline UB & $\mathrm{CSOUB}_{1,100 \mathrm{C}}$ & $98: 26$ & $93.00: 31.00$ & 0.8709 & 0.35 \\
\hline UB & Satt-547 & $99: 25$ & $93.00: 31.00$ & 1.5484 & 0.21 \\
\hline UB & Satt-431 & - & - & - & - \\
\hline
\end{tabular}

${ }^{1 /}$ Expected proportion for acceptance of the independence hypothesis was 3:1. resistance or presence of DNA band:susceptibility or absence of band. In the case of population UB locus Rcs3, the expected proportion for independence was 13:3.

${ }^{2 /}$ Resistance to C. sojina locus.

${ }^{3 /}$ Monomorphic for this cross.

\section{Conversion of RAPD marker into a SCAR}

The DNA fragment corresponding to RAPD marker CSOPA $2_{1,250 \mathrm{C}}$ was cloned and partially sequenced. Two 18-nucleotide-long primers were synthesized based on the sequencing data: SCARBG5F (5' GCC GTG AGA AAG GCG AAG 3') and SCARBG5R (5' AGC CGT GAA TTA TCC GAT 3'). These primers were tested in the CB and PB $\mathrm{F}_{2}$ populations, and Figure 2 shows that the polymorphism of the amplifications is identical to the one revealed by the RAPD marker. This SCAR marker can be used for markerassisted selection in programs aiming at the development of cultivars which are resistant to frogeye leaf spot, particularly when other traits are also being evaluated.

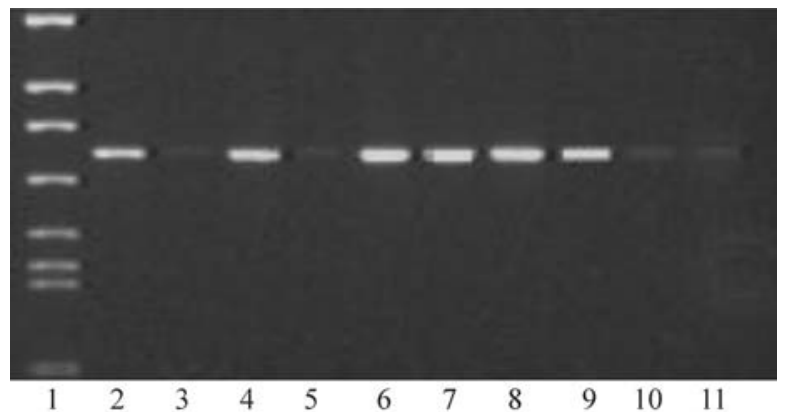

Figure 2 - Transformation of RAPD marker CSOPA2 $2_{1,250 \mathrm{C}}$ into SCAR marker. Lanes are as follows: 1, lambda phage DNA digested with EcoRI, BamHI and HindIII (size markers); 2, resistant Parana cultivar; 3, susceptible Bossier cultivar; 4, resistant bulk; 5, susceptible bulk; 6-9, resistant $\mathrm{F}_{2}$ plants; and 10-11, susceptible plants.

Table II - Analyses of linkage between RAPD markers and resistance to Cercospora sojina Hara locus in $\mathrm{F}_{2}$ populations derived from the crosses 'Cristalina' x 'Bossier' (CB), 'Parana' x 'Bossier' (PB) and 'Uberaba' x 'Bossier' (UB) ${ }^{1 /}$.

\begin{tabular}{|c|c|c|c|c|c|}
\hline Population & Locus tested & Observed frequency & $\chi^{2}$ & $\mathrm{p}$ & $\mathrm{CM} \pm \mathrm{SD}^{2}$ \\
\hline $\mathrm{CB}$ & $\operatorname{Rcs} 3 / \operatorname{CSOPA} 1_{800 \mathrm{C}}$ & $158: 4: 1: 56$ & 214.63 & & $2.3 \pm 1.2$ \\
\hline $\mathrm{CB}$ & $\operatorname{Rcs} 3 /$ CSOPA2 $2_{1,250 \mathrm{C}}$ & $154: 8: 1: 56$ & 211.49 & & $4.7 \pm 1.5$ \\
\hline PB & $\operatorname{Rcs} 3 / \mathrm{CSOPA} 1_{800 \mathrm{C}}$ & $94: 4: 1: 27$ & 92.98 & & $4.4 \pm 1.8$ \\
\hline PB & Rcs 3 / CSOPA $2_{1,250 \mathrm{C}}$ & $94: 4: 0: 28$ & 99.99 & & $3.4 \pm 1.7$ \\
\hline UB & $\operatorname{Rcs} 3 / \mathrm{CSOPA} 1_{800 \mathrm{C}}$ & $97: 6: 0: 21$ & 69.81 & & $5.6 \pm 2.1$ \\
\hline UB & $\mathrm{Rcs} 3 / \mathrm{CSOUB}_{1,100 \mathrm{C}}$ & $97: 6: 1: 20$ & 64.53 & & $6.7 \pm 2.2$ \\
\hline
\end{tabular}

${ }^{1 /}$ Expected proportion for acceptance of the independence hypothesis was 9:3:3:1 presence of resistance locus and marker: presence of resistance locus and absence of marker: absence of resistance locus and presence of marker: absence of resistance locus and marker.

${ }^{2 /}$ Genetic distance in centiMorgans \pm standard deviation. 


\section{Acknowledgments}

The authors thank BID/FINEP and FAPEMIG for financial support. SMF was supported by a fellowship from CNPq.

\section{References}

Arias CAA, Yorinori JT, Toledo JFF and Kiihl RAS (1996) Inheritance of resistance of soybean [Glycine max (L.) Merrill] to races 4 and 15 of frogeye leaf spot fungus (Cercospora sojina Hara). Braz J Genet 19:295-304.

Casela CR, Noguez MA, Luzzardi CG and Gastal MFC (1979) Mancha "olho-de-rã" (Cercospora sojina Hara) em soja (Glycine $\max$ (L.) Merrill). EMBRAPA/CNPSo. I National Meeting on Soybean Research, Londrina, PR, Brazil, v. 2, pp 139-143.

Cordeiro ACC (1986) Herança da resistência da soja (Glycine max (L.) Merrill), à Cercospora sojina Hara, isolado de São Gotardo, Minas Gerais. M.S. Thesis. Federal University of Viçosa, Viçosa, MG, Brazil.

Cregan PB, Jarvik T, Bush AL, Shoemaker RC, Lark KG, Kahler AL, Kaya N, VanToai TT, Lones DG, Chung J and Specht JE (1999) An integrated genetic linkage map of the soybean genome. Crop Sci 39:1464-1490.

Doyle JJ and Doyle JL (1990) Isolation of plant DNA from fresh tissue. Focus 12:13-15.

Keim P, Shoemaker RC and Palmer RG (1989) Restriction fragment length polymorphism diversity in soybean. Theor Appl Genet 77:786-792.

Lander ES, Green P, Abrahamson J, Barlow A, Daly MJ, Lincoln SE and Newburgh L (1987) Mapmaker: An interactive computer package for construting primary genetic linkage maps of experimental and natural populations. Genomics 1:174-181.
Lincoln SE, Daly MJ and Lander ES (1992) Constructing genetic maps with Mapmaker/EXP 3.0. 3 ed, s 1, Whitehead Institute, Technical Report.

Machado MA, Barros EG, Vasconcelos MJV, Gomes JLL and Moreira MA (1997) RAPD analysis for the characterization of Cercospora sojina isolates. Brazilian Phytopathology 22:366-369.

Mian MAR, Wang T, Phillips DV, Alvernaz J and Boerma R (1999) Molecular mapping of the Rcs3 gene for resistance to frogeye leaf spot in soybean. Crop Sci 39:1687-1691.

Michelmore RW, Paran I and Kesseli RV (1991) Identification of markers linked to disease-resistance genes by bulked segregant analysis: A rapid method to detect markers in specific genome regions by using segregating populations. Proc Natl Acad Sci USA 88:9828-9832.

Shoemaker RC, Guffi RD, Lorenzen LL and Specht JE (1992) Molecular genetic mapping of soybean: map utilization. Crop Sci 32:1091-1098.

Veiga P (1973) Cercospora sojina Hara: obtenção de inoculo, inoculação e avaliação da_resistência em soja (Glycine max (L.) Merrill). M.S. Thesis. ESALQ/USP, Piracicaba, SP, Brazil.

Williams J, Kubelik A, Livak K, Rafalski A and Tingey S (1990) DNA polymorphisms amplified by arbitrary primers are useful as genetic markers. Nucl Ac Res 18:6531-6535.

Yorinori JT (1989a) Frog eye leaf spot of soybean (Cercospora sojina Hara). World Soybean Research Conference - IV, March 5-9, v. III. Buenos Aires, Argentina, pp 1275-1283.

Yorinori JT (1989b) Identificação de raças de Cercospora sojina Hara e distribuição geográfica no Brasil. EMBRAPA/ CNPSo. V National Seminar of Soybean Research, Campo Grande, MS, Brazil, pp 31-32.

Young R, Melotto M, Nodari RO and Kelly JD (1998) Markerassisted dissection of the oligogenic anthracnose resistance in the common bean cultivar G2333. Theor Appl Genet 96:87-94.

Young R and Kelly JD (1996) RAPD markers flanking the Are gene for anthracnose resistance in common bean. J Amer Soc Hort Sci 121:37-41. 